\title{
Effect of Vanadium Compounds on Acid Phosphatase Activity
}

\author{
Cecilia M. Vescina, ${ }^{1}$ Viviana C. Sálice, ${ }^{1}$ \\ Ana M. Cortizo, ${ }^{1}$ And Susana B. ETCheverry ${ }^{*}, 1,2$ \\ 'Cátedra de Bioquímica Patológica, ${ }^{2}$ Programa QUINOR, \\ Facultad de Ciencias Exactas, Universidad Nacional de La Plata \\ 47 y 115. 1900 La Plata, Argentina \\ Received January 16, 1995; Accepted March 3, 1995
}

\begin{abstract}
The direct effect of different vanadium compounds on acid phosphatase (ACP) activity was investigated. Vanadate and vanadyl but not pervanadate inhibited the wheat germ ACP activity. These vanadium derivatives did not alter the fibroblast Swiss 3T3 soluble fraction ACP activity. Using inhibitors of tyrosine phosphatases (PTPases), the wheat germ ACP was partially characterized as a PTPase. This study suggests that the inhibitory ability of different vanadium derivatives to modulate $A C P$ activity seems to depend on the geometry around the vanadium atom more than on the oxidation state. Our results indicate a correlation between the PTPase activity and the sensitivity to vanadate and vanadyl cation.
\end{abstract}

Index Entries: Vanadium; acid phosphatase; Tyrosine-phosphatase; fibroblast cells; inhibitory effects.

\section{INTRODUCTION}

Vanadium is a trace element that has been shown to affect directly the activity of several enzymes in vitro (1-6): $\mathrm{Na}^{+} / \mathrm{K}^{+}$-ATPase, alkaline, and acid phosphatase, glucose-6-phosphate dehydrogenase, $\mathrm{Cu}-\mathrm{Zn}$ superoxide dismutase, and several phosphotyrosine protein phosphatases (PTPases). Additionally, it is a potent insulinomimetic agent in isolated adipocytes and hepatocytes $(7,8)$. We have recently shown that vanadium derivatives also behave as growth factor-mimetic compounds

*Author to whom all correspondence and reprint requests should be addressed. 
in osteoblast-like cells in culture (9). The mechanism of action of vanadium is not completely understood. It has been postulated that vanadate binds several proteins since its structure is analogous to that of phosphate (10). However, vanadium compounds with different oxidation state and structure also show bioactivity $(2,3,9)$. The aim of this study was to investigate the direct effect of different vanadium compounds on acid phosphatase (ACP) activity. We also attempted to characterize the ACP activity as PTPase and find a relationship with its sensitivity to several vanadium compounds.

\section{MATERIALS AND METHODS}

\section{Materials}

Vanadium (IV) oxide sulfate (vanadyl sulfate) was obtained from Merck, sodium $o$-vanadate, $p$-nitrophenylphosphate (pNPP) and catalase were obtained from Sigma (St Louis, MO), as well as the wheat germ acid phosphatase (ACP). Tissue-culture material was provided by Corning or Falcon. Dulbecco's Modified Eagle's Medium (DMEM) and trypsin-EDTA were supplied by Gibco (Gaithersburg, MD) and fetal bovine serum (FBS) by Gen (Argentina). All other chemicals used were of analytical grade from Sigma.

\section{Solutions}

Fresh stock solutions of vanadyl (V [IV]) sulfate and sodium $o$-vanadate (V [V]) were prepared in distilled water at $100 \mathrm{mM}$ concentration. Pervanadate (V [V]) was prepared as previously reported (4).

\section{Cell Culture}

Fibroblasts Swiss 3 T3 were grown in DMEM supplemented with 100 $\mathrm{U} / \mathrm{mL}$ penicillin, $100 \mu \mathrm{g} / \mathrm{mL}$ streptomycin, and $10 \%$ (v/v) FBS. Cells were passed by Trypsin-EDTA treatment when they became $70 \%$ confluent. Swiss 3T3 were chosen since they are a line of fibroblast cells that has been extensively used to investigate cell division as well as the effect of growth factors and other agents with potential mitogenic actions (11). For the experiments, cells were grown in $70 \mathrm{~cm}^{2}$ flasks. After the cells reached confluence, the medium was removed and the monolayer was washed twice with phosphate buffered saline (PBS) pH 7.4 and once with $50 \mathrm{mM}$ HEPES/150 $\mathrm{mM} \mathrm{NaCl}$ buffer containing $1 \mathrm{mM}$ EDTA, $15 \mathrm{mM}$ $\beta$-mercaptoethanol and $1 \mathrm{mM}$ phenylethanosulfonyl fluoride.

\section{Preparation of Cellular Fractions}

Cells were scraped in the above buffer and sonicated at $600 \mathrm{psi} / 15 \mathrm{~s}$. The homogenate was centrifuged at $2500 \mathrm{rpm} / 5 \mathrm{~min}$. The supernatant 
was centrifuged at $45,000 \mathrm{~g} / 90 \mathrm{~min}$ at $4^{\circ} \mathrm{C}$. The supernatant (soluble fraction) was stored at $-70^{\circ} \mathrm{C}$. The pellet was solubilized in $50 \mathrm{mM}$ HEPES/ $150 \mathrm{mM} \mathrm{NaCl} / 1 \%$ Triton-X100 and recentrifuged as before. The final supernatant (particulate fraction) was stored at $-70^{\circ} \mathrm{C}$. Aliquots of both fractions were used in protein assay by the Bradford method (12).

\section{Acid Phosphatase Activity (ACP)}

The ACP activity from wheat germ was determined as described by Crans (2). In brief, pNPP ( $5 \mathrm{mM})$ was used as a substrate in $50 \mathrm{mM}$ sodium acetate buffer, $\mathrm{pH} 5.0$, in the presence of $20 \mathrm{mM} \mathrm{KCl}$ and $30 \mathrm{mM}$ $\mathrm{MgCl}_{2}$ (assay buffer). Incubation was carried out at $37^{\circ} \mathrm{C}$ for $10 \mathrm{~min}$ and absorbance at $405 \mathrm{~nm}$ was measured in order to determine the initial rate of the activity. Under these experimental conditions, the reaction was linear for $15 \mathrm{~min}$.

The initial rate of ACP activity in the soluble and particulate fractions of Swiss 3T3 cells was determined by incubation of $73.5 \mathrm{mg}$ of protein (soluble) and $43 \mathrm{mg}$ of protein (particulate) in assay buffer. Absorbance at $405 \mathrm{~nm}$ was monitored at $37^{\circ} \mathrm{C}$ during $2 \mathrm{~min}$. Under these conditions, the reaction proceeded linearly for $5 \mathrm{~min}$. The effect of different vanadium compounds and other agents was tested in coincubations with the different enzymes. The inhibitory effect was determined as the percentage of the basal initial velocity of the ACP activity.

\section{Statistical Analysis}

The results are expressed as mean \pm SEM ( $n=$ number of cases). Statistical differences were analized using Student's $t$-test or analysis of variance (ANOVA) when suitable.

\section{RESULTS AND DISCUSSION}

\section{Effects of Vanadium Compounds on Wheat \\ Germ Acid Phosphatase Activity}

Three different forms of ACP have been isolated and characterized from commercial wheat germ (13). We have chosen the wheat germ acid phosphatase as a model of a phosphatase sensitive to vanadium compounds. Figure 1 shows the dose-response effects of vanadate, vanadyl cation, and pervanadate on wheat germ ACP activity. Vanadate and vanadyl effectively inhibited the enzyme at doses as low as $5 \mu \mathrm{M}$. Doseresponse curves show a similar effect of these compounds in the range of 5-50 $\mu M$. However, at higher concentrations, vanadate was a stronger inhibitor than vanadyl cation.

Pervanadate has been proved to be a more potent agent than vanadate in different in vitro systems (14). We have recently shown that peroxo 


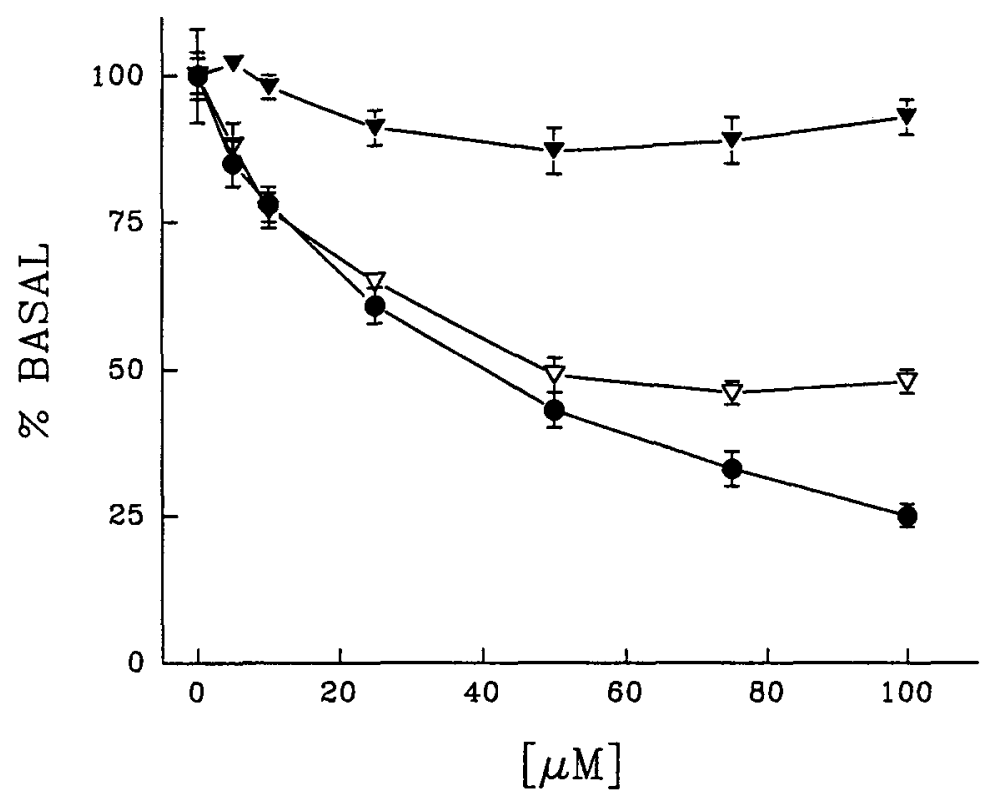

Fig. 1. Effect of vanadate, vanadyl, and pervanadate on wheat germ ACP activity. Initial rate was determined by incubation of the enzyme $(50 \mu \mathrm{g} / \mathrm{mL})$ at $37^{\circ} \mathrm{C}$ for $10 \mathrm{~min}$ in the absence or presence of variable concentrations of the compounds. Basal activity was $15.1 \pm 0.43 \mathrm{nmol} / \mathrm{min} / \mathrm{mg}$ protein $(n=6)$. $\bullet$, Vanadate; $\nabla$, vanadyl; $\nabla$, pervanadate.

vanadium compounds as well as vanadate, selectively inhibited a bone soluble alkaline phosphatase (4). In the present study, we tested the effect of pervanadate on ACP activity. As can be seen in Fig. 1, this compound did not induce a significant effect in the in vitro assay of ACP activity.

This pattern of action of vanadium compounds on wheat germ acid phosphatase was similar to that previously found for the bovine intestinal alkaline phosphatase (4). Crans et al. (2) previously showed the ability of vanadate and vanadyl to inhibit the ACP enzyme. However, there are no previous studies that reported the direct in vitro pervanadate effect on these phosphatases.

These results would suggest that the inhibitory ability of different vanadium derivatives to modulate phosphatase activity, possibly, depends on the geometry around the vanadium atom more than on the oxidation state.

\section{Effect of Vanadium Compounds on Swiss 373 Fibroblast ACP Activity}

Table 1 shows the action of vanadium derivatives on the soluble fraction of fibroblasts. As can be seen, only vanadyl cation induced a weak but statistically significant inhibition. 
Table 1

Effect of Vanadium Compounds on ACP Activity from Soluble Fraction of Swiss 3T3 Cells ${ }^{a}$

\begin{tabular}{lcc}
\hline Compound & Percent basal activity & Difference vs basal \\
\hline- & $100 \pm 1$ & \\
$100 \mu M$ Vanadate & $111 \pm 5$ & NS \\
$100 \mu M$ Vanadyl & $95 \pm 1$ & $p<0.05$ \\
$100 \mu M$ Pervanadate & $101 \pm 5$ & NS \\
\hline
\end{tabular}

aResults are expressed as mean \pm SEM, $n=3$.

NS, not significant.

Table 2

Effect of Different Agents on ACP Activity ${ }^{a}$

\begin{tabular}{lcc}
\hline & \multicolumn{2}{c}{$\%$ Basal activity } \\
\cline { 2 - 3 } Agent & Wheat germ & Soluble fraction fibroblasts \\
\hline- & $100 \pm 3.6$ & $100 \pm 10$ \\
$100 \mu M$ Zn sulfate & $95 \pm 9$ & $102 \pm 6$ \\
$100 \mu M$ NH$_{4}$ molibdate & $5 \pm 1.8^{b}$ & $107 \pm 3$ \\
5 mM EDTA & $165 \pm 20 c$ & - \\
\hline
\end{tabular}

aResults are expressed as mean $\pm \mathrm{SEM}, n=3$. Differences vs basal are: $b_{p}<0.001, c p<0.05$.

The fibroblast particulate fraction showed very little ACP activity and it was not inhibited by any of the tested vanadium derivatives (data not shown).

\section{Partial Characterization of ACP Activity}

It is well known that different compounds can act as modulators of protein phosphotyrosin phosphatases (PTPases) (15). In order to partially characterize the ACP activity, we tested molybdate, $\mathrm{Zn}+2$ and EDTA on ACP from wheat germ and from the soluble fraction of fibroblast cells. Table 2 shows the results of this study. The wheat germ ACP activity was strongly inhibited by molibdate $(p<0.001)$ and weakly by $\mathrm{Zn}^{+2}$ (no statistical significance). Additionaly, EDTA increased its activity about 1.5 fold $(p<0.05)$. These observations together with the $75 \%$ inhibition of 100 $\mu M$ vanadate suggest that this $A C P$ activity behaves as a PTPase.

On the other hand, the ACP in the soluble fraction of fibroblasts was not modulated by the above-mentioned chemical agents. These results together with the lack of inhibition by vanadium derivatives suggest 
that, under our experimental conditions, the amount of PTPase activity in the soluble fraction of fibroblasts would be negligible.

It has been proposed that vanadate selectively inhibits phosphotyrosine phosphatases relative to phosphoserine or phosphothreonine phosphatases (16). However, the mechanism for this selectivity is not clear.

Although we did not measure PTPase directly, the use of additional chemical modulators of the enzyme as Zn, molybdate, and EDTA, allow us to suggest the presence of this kind of activity in the wheat germ ACP. Our results indicate a correlation between the PTPase activity and the sensitivity to vanadate and vanadyl cation.

\section{ACKNOWLEDGMENTS}

The authors would like to thank Lic. M. C. Apezteguía for helping in statistical analysis, D. A. Barrio for experimental assistance, and $\mathrm{N}$. Fenoglio for revision of the manuscript language. S. B. Etcheverry is a member of Carrera del Investigador CONICET (Argentina) and A. M. Cortizo is a member of Carrera del Investigador CICPBA (Argentina). This work was partially supported by the School of Exact Sciences, UNLP, Argentina.

\section{REFERENCES}

1. L. C. Cantley Jr., L. Josephson, R. Warner, M. Yanagisawa, C. Lechene, and G. Guidotti, Vanadate is a potent (Na-K) ATPase inhibitor found in ATP derived from muscle, J. Biol. Chem. 252, 7421-7423 (1977).

2. D. C. Crans, R. L. Bunch, and L. A. Theisen, Interaction of trace levels of vanadium (IV) and vanadium (V) in biological systems, J. Am. Chem. Soc. 111, 7597-7607 (1989).

3. D. C. Crans and S. M. Schelble, Vanadate dimer and tetramer both inhibit glucose6-phosphate dehidrogenase from Leuconostoc mesenteroides, Biochemistry 29, 6698-6706 (1990).

4. A. M. Cortizo, V. C. Salice, and S. B. Etcheverry, Vanadium compounds. Their action on alkaline phosphatase activity, Biol. Trace Elem. Res. 41, 331-339 (1994).

5. M. C. Apella, S. N. Gonzáles, and E. J. Baran, The inhibitory effect of vanadium oxoanions on the activity of copper-zinc superoxide dismutase, Biol. Trace Elem. Res. 18, 123-130 (1988).

6. K. H. W. Lau, J. R. Farley, and D. J. Baylink, Phosphotyrosyl protein phosphatases, Biochem J. 257, 23-36 (1989).

7. W. C. Duckworth, S. S. Solomons, J Liepnieks, F. G. Hamel, S. Hand, and D. E. Peavy, Insulin-like effects of vanadate in isolated rat adipocytes, Endocrinology 122, 2285-2289 (1988).

8. C. Villar Palasi, J. J. Guinovart, A. M. Gómez-Foix, J. E. Rodríguez Gil, and F. Bosch, Effects of vanadate on protein kinases in rat hepatocytes, Biochem J. 262, 563-567 (1989).

9. A. M. Cortizo and S. B. Etcheverry, Vanadium derivatives act as growth factor mimetic compounds upon differentiation and proliferation of osteoblast-like UMR 106 cells, Mol. Cell. Biochem. 145, 97-102 (1995).

10. I. G. Macara, Vanadium-An element in search of a role, Trends Biochem. Sci. 5, 92-94 (1980). 
11. A. N. Corps and K. D. Brown, Mitogens regulate the production of insulin-like growth factor binding protein by Swiss $3 T 3$ cells, Endocrinology 128, 1057-1064 (1991).

12. N. Bradford, A rapid and sensitive method for the quantitation of microgram quantities of protein utilizing the principle of protein-dye bind, Anal. Biochem. 72, 248-254 (1976).

13. Z. H. M. Verjee, Isolation of three acid phosphatases from wheat germ, Euro. J. Biochem. 9, 439-444 (1969).

14. S. Kadota, I. G. Fantus, G. Deragon, H. J. Guyda, and B. I. Posner, Stimulation of insulin-like growth factor II receptor binding and insulin receptor kinase activity in rat adipocytes, J. Biol. Chem. 262, 8252-8256 (1987).

15. N. K. Tonks, C. D. Diltz, and E. H. Fisher, Purification of the major protein-tyrosinephosphatases of human placenta, J. Biol. Chem. 263, 6722-6730 (1988).

16. R. L. Nelson and P. E. Branton, Identification, purification and characterization of phosphotyrosine-specific protein phpsphatases from cultured chicken embryo fibroblasts, Mol. Cell Biol. 4, 1003-1012 (1984). 